\title{
PROGRAM PENGABDIAN KEPADA MASYARAKAT: PELATIHAN PEMANFAATAN SALURAN IRIGASI UNTUK PEMBANGKIT LISTRIK MICROHIDRO KEPADA MASYARAKAT DI DESA PAMIJAHAN GUNUNG BUNDER
}

\author{
Yani Prabowo'), Suwasti Broto' ${ }^{2)}$, dan Grace Gata ${ }^{3)}$ \\ ${ }^{1,3}$ Fakultas Teknologi Informasi, Universitas Budi Luhur \\ ${ }^{2}$ Teknik elektro, Universitas Budi Luhur \\ $1,2,3$ Ciledug raya.Petukangan Jakarta Selatan 12260 \\ E-mail : yani.prabowo@budiluhur.ac.id ${ }^{1)}$, suwasti.broto@budiluhur.ac.id ${ }^{2)}$, grace.gata@budiluhur.ac.id ${ }^{3)}$
}

\begin{abstract}
ABSTRAK
Listrik sampai saat ini sudah menjadi kebutuhan yang cukup penting, tetapi belum semua wilayah dapat terjangkau oleh aliran listrik. Hal tersebut bisa disebabkan karena suatu wilayah mempunyai medan yang sulit diakses oleh sarana transportasi. Bermacam cara dapat digunakan untuk menghasilkan sumber daya listrik seperti menggunakan bahan bakar minyak, menggunakan pembangkit listrik tenaga matahari dan bisa menggunaan tenaga air. Desa Gunung Bunder Pamijahan Bogor mempunyai potensi air yang dapat dimanfaatkan sebagai pembangkit listrik tenaga microhidro, tetapi sampai saat ini warga sekitar belum mengetahui bagaimana cara memanfaatkan aliran sungai tersebut. Melalui kegiatan pengabdian pada masyarakat oleh Universitas Budi Luhur, telah dilakukan pelatihan dan penyuluhan untuk pembuatan pembangkit listrik tenaga air dengan kincir model vortex dengan menggunakan bahan-bahan yang mudah didapatkan disekitar desa. Pemilihan menggunakan turbin vortex berdasarkan pertimbangan ketingian pada lokasi kincir tersebut yang hanya memiliki ketinggian 4.33 meter tetapi memiliki aliran debit yang cukup untuk mengerakan turbin. Potensi yang berhasil didapat dari penelitian ini dengan beda ketinggian (head) 2.6 meter dari panjang lintasan 4 stasiun dengan jarak masing masing antar stasiun 26 meter. Kecepatan air rata-rata 10 liter perdetik akan menghasilkan daya sebesar 254.604 watt. Hal tersebut masih dapat dikembangan untuk mendapatkan daya yang maksimal dengan mengkondisikan saluran air pada saluran irigasi.
\end{abstract}

Kata Kunci: Turbin, Microhidro,Irigasi, Listrik, Tenaga Air

\section{PENDAHULUAN}

Listrik sampai saat ini sudah menjadi kebutuhan yang cukup penting, tetapi belum semua wilayah dapat terjangkau oleh aliran listrik. Hal tersebut bisa disebabkan karena suatu wilayah mempunyai medan yang sulit diakses oleh sarana transportasi. Bermacam cara dapat digunakan untuk menghasilkan sumber daya listrik seperti menggunakan bahan bakar minyak, menggunakan pembangkit listrik tenaga matahari dan bisa menggunaan tenaga air. Seiring dengan kemajuan teknologi di segala bidang, maka catu daya utama PLN (Perusahaan listrik Negara) sangat berpengaruh terhadap penyedian energi listrik bagi layanan publik. Akan tetapi suplai daya utama yang berasal dari PLN (Perusahaan Listrik Negara) tidak selamanya kontinu dalam penyalurannya. Suatu saat pasti terjadi pemadaman total yang dapat disebabkan oleh gangguan pada sistem pembangkit, atau gangguan pada sistem transmisi dan sistem distribusi (Safii and Vidy, 2019). Jika pembangkit listrik mengunakan bahan bakar minyak tentunya sangat mahal untuk biaya operasional pembangkit listrik dan belum tentu semua masyarakat bisa membayar operasional pembangkit listrik tersebut. Jika menggunakan sistem pembangkit tenaga surya, mempunyai kelemahan modul pembangkit tersebut sampai saat ini masih tergolong cukup mahal.
Pembangkit listrik microhidro (PLMTH) merupakan salah satu alternatif yang cukup murah dan ramah lingkungan untuk mendapatkan energi listrik (Subandono, 2013). Desa Gunung Bunder Pamijahan Bogor sampat saat ini ada sebagian wilayah yang belum teraliri jaringan listrik. Sebagian besar mata pencarian masyarakat adalah petani, didesa tersebut memiliki sumber daya air yang melimpah sampai saat ini belum tersentuh untuk dikembangkan dan dimanfaatkan airnya. Selama ini air tersebut hanya untuk kebutuhan dasar seperti mandi, mencuci, dan irigasi selebihnya air tersebut hanya mengalir ke sungai. Di sisi lain ada masyarakat yang sampai saat ini belum mendapat aliran listrik dari PLN.Melihat hal tersebut kami mencoba mencarikan alternatif lain untuk memberikan penerangan kepada masyarakat dengan memperkenalkan energi listrik yang didapat dari sumber aliran sungai yang ada pada desa tersebut.

Pemanfaatan aliran sungaI sebagai lokasi untuk pembangkit listrik microhidro pernah dilakukan (Pranoto et al., 2018) bahwa Potensi energi mikrohidro di saluran irigasi dapat menghasilkan energi listrik menggunakan teknologi hidroelektrik. Saluran irigasi yang terdapat di daerah pertanian-pertanian di pedesaan mempunyai potensi untuk dimanfaatkan sebagai pembangkit listrik. 
Aliran air di saluran irigasi mempunyai kestabilan aliran debit lebih stabil dibandingkan dengan aliran debit air di sungai. Debit air di aliran irigasi relatif tidak terpengaruh oleh perubahan musim atau cuaca. Kondisi ini sangat menguntungkan untuk pemanfaatan pembangkit listrik yang menuntut kesinambungan suplai air yang tinggi.(Febijanto, 2011). Dengan memanfaatkan ketinggian air pada 2,5 meter sudah dapat menghasilkan daya listrik sebesar 400 watt hal tersebut dilakukan oleh (Bahtiar, A., Hidayat, D. and J.M., Syakir, N and Wibawa, 2015).

Dengan mempertimbangkan latar belakang yang telah diutarakan di atas, kami mengadakan program pengabdian pada masyarakat untuk melakukan pembuatan pembangkit listrik tenaga air microhidro. Selain itu membangun PLMTH adalah upaya konstruktif untuk mengajak masyarakat peduli dengan lingkungan hidup secara riil. Dengan menjaga kualitas hutan untuk menghasilkan air yang bermanfaatkan untuk memutar turbin pembangkit listrik. PLTMH adalah suatu pembangkit listrik skala kecil (kurang dari 100kW) yang menggunakan tenaga air sebagai penggeraknya seperti saluran irigasi, sungai atau air terjun dengan cara memanfaatkan tinggi terjunan (head) dan jumlah debit air.

PLMTH pada dasarnya memanfaatkan energi potensial head. Semakin tinggi head maka semakin besar energi potensial air yang dapat diubah menjadi energy listrik. (Nasir, 2013) Disamping faktor geografis, head juga dapat pula diperoleh dengan membendung air menjadi tinggi. Air dialirkan melalui sebuah pipa ke dalam rumah pembangkit yang pada umumnya dibangun ditepian sungai. Pada prinsipnya pembangkit listrik microhidro adalah sama dengan pembangkit listrik tenaga air hanya yang membedakan. PLMTH micro ini dapat beroperasi tanpa harus membuat reservoir untuk menampung air dalam jumlah besar. pembangkit listrik tenaga air dengan skala kecil dengan batasan kapasitas antara $5 \mathrm{~kW}-1 \mathrm{MW}$ perunit sedangkan pendapat lain sistem pembangkit micro hidro digolongkan menjadi 3, yaitu minihidro dengan kapasitas $100 \mathrm{KW}$ s/d $1 \mathrm{MW}$, mikro hidro dengan kapasitas 1- $100 \mathrm{KW}$ dan piko hidro dibawah $1 \mathrm{KW}$. Pembangkit Listrik Tenaga Mikrohidro (PLTMH) adalah suatu sistem pembangkit listrik yang dapat mengubah potensi air dengan ketinggian dan debit tertentu menjadi tenaga listrik, dengan menggunakan turbin air dan generator. Cara kerja dari pembangkit ini cukup sederhana, yaitu menggerakkan turbin dengan memanfaatkan aliran air. (Shantika, 2013).

Turbin open flume merupakan suatu jenis turbin air berskala mikro yang cocok digunakan pada daerah terpencil dengan karakteristik geografi bergununggunung karena pembuatannya yang sederhana dan perawatannya yang mudah. Tinggi jatuh air yang dapat digunakan turbin ini berkisar antara $2-10 \mathrm{~m}$ sehingga memiliki cakupan daerah penggunaan yang luas. (Budiarso Muhammad Ridho dan Raza Dianofitra, 2014).

Turbin tersebut berfungsi untuk mengubah energi yang tersedia menjadi energi mekanik. Salah satu sistem yang digunakan oleh PLTMH adalah mikro hidro vortex. turbin vortex menggunakan energi kinetik air yang membentuk pusaran yang akan menggerakkan sudu turbin. Untuk mendapatkan efisiensi turbin yang optimal, maka salah satu faktor yang dapat ditinjau adalah pemilihan profil atau model turbin yang sesuai. Penelitian mengenai turbin vortex ini juga dilakukan oleh Ray Sihombing, Syahril Gultom tahun 2014 adalah untuk mendapatkan rancangan casing turbin vortex, rancangan poros, rancangan sudu dan bantalan serta bahan- yang sesuai. Turbin Vortex ini dirancang dengan debit air 0.0052 dan kecepatan air $1.44 \mathrm{~m} / \mathrm{s}$ (Sihombing et al., 2014) (Syafitri et al., 2018). Penggunaan turbin vortex sangat cocok daerah yang memiliki karakteristik geografis yang ber gunung-gunung, seperti dilakukan oleh farid dan Priyo tahun 2018 meneliti mengenai turbin vortex dengan beberapa tipe sudu untuk menghasilkan daya yang maksimal (Farid rahman, 2018). Pembangkit Listrik Tenaga Mikro Hidro (PLTMH) pada dasarnya sebuah pembangkit Listrik Tenaga Air (PLTA) dimana memerlukan dua data yang penting yaitu debit air dan ketinggian jatuh (biasa disebut 'Head') untuk menghasilkan tenaga yang bermanfaat. Ini adalah sebuah sistem konversi tenaga, menyerap tenaga dari bentuk ketinggian dan aliran, dan menyalurkan tenaga dalam bentuk daya mekanik ke daya listrik. Tidak ada sistem konversi daya yang dapat mengirim sebanyak yang diserap karena sebagian daya hilang oleh sistem itu sendiri dalam bentuk gesekan, panas, suara dan sebagainya (Zainuddin et al., 2009).

Persamaan konversinya adalah: Daya yang masuk = Daya yang keluar + Kehilangan (Loss) atau Daya yang keluar $=$ Daya yang masuk $\times$ Efisiensi konversi

Daya kotor adalah tinggi terjun kotor (Hgross) yang dikalikan dengan debit air (Q) dan juga dikalikan dengan sebuah faktor gaya gravitasi $(\mathrm{g}=9.8)$, sehingga persamaan dasar dari pembangkit listrik adalah :

$$
\text { Pnett }=\text { gxH gross } x Q \times \mu t o t
$$

dimana head dalam meter, dan debit air dalam meter kubik per detik, dan $\mu$ tot ( effisiensi total ) dalam persen dan terbagi sebagai berikut :

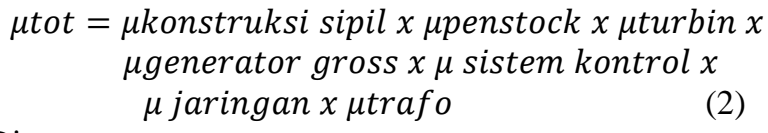

Di mana :

$\mu$ konstruksi sipil : $1.0-$ (panjang saluran $\times 0.002$ 0.005)/ Hgross

upenstock $\quad: 0.90 \quad-0.95$ (tergantung pada panjangnya)

$\mu$ turbin $\quad: 0.70-0.85$ (tergantung pada tipe turbin)

$\mu$ generator $\quad: 0.80 \quad-0.95$ (tergantung pada kapasistas generator)

$\mu$ sistem kontrol $\quad: 0.97$ 


$\begin{array}{ll}\mu \text { jaringan } & : 0.90-0.98 \text { (tergantung pada } \\ & \text { panjang jaringan) } \\ \mu \text { trafo } & : 0,98\end{array}$

$\mu$ konstruksi sipil dan penstock adalah yang biasa diperhitungkan sebagai 'Head Loss (Hloss) atau kehilangan ketinggian'. Dalam kasus ini, persamaan diatas dirubah ke persamaan berikut.

$$
\begin{aligned}
& \text { Pnett }=g x(\text { Hgross }- \text { Hloss }) x Q x(\mu \text { tot }-
\end{aligned}
$$

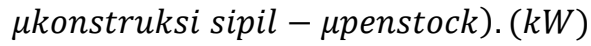

Pemilihan jenis turbin yang digunakan sangat tergantung dari besarnya debit air dan tinggi jatuh air yang tersedia, besarnya harga dari debit dan tinggi jatuh air ini didapatkan dari hasil survei dilapangan pada pengamatan sebelumnya dilokasi tersebut didapat data Potensi yang berhasil didapat dari penelitian ini dengan beda ketinggian (head) 2.6 meter dari panjang lintasan 4 stasiun dengan jarak masing masing antar stasiun 26 meter. Kecepatan air rata-rata 10 liter perdetik akan menghasilkan daya sebesar 254.604 watt. Sistem pembangkit microhidro ini tidak menggunakan metode bendungan tetapi menggunakan turbin kaplan yang dimodifikasi menjadi turbin vortex (Prabowo et al., 2018).

\section{RUANG LINGKUP}

Dalam pengabdian ini mencakup:
1. Cakupan permasalahan adalah bagaimana cara memanfaatkan secara maksimal sumber daya air di desa Gunung Bunder Pamijahan Bogor sebagai sumber energi alternatif melalui Pembangkit Listrik Tenaga Mikrohidro (PLTMH) dengan masyarakat sekitar.

2. Batasan-penelitian pengabdian masyarakat ini adalah mengajarkan kepada masyarakat untuk dapat menyediakan listrik secara mandiri berdasarkan potensi yang ada dilingkungan sekitar dengan menggunakan turbin air.

3. Rencana hasil yang didapatkan adalah terlaksananya pembangunan Pembangkit Listrik Tenaga Mikrohidro (PLTMH) di desa Gunung Bunder Pamijahan Bogor. tersebut dapat memenuhi sebagian kebutuhan listrik masyarakat desa Gunung Bunder Pamijahan Bogor

\section{BAHAN DAN METODE}

Program yang dilaksanakan pada kegiatan ini terdiri dari persiapan, pelaksanaan. Pada pelaksanaan dan evaluasi kegiatan pengabdian kepada masyarakat berupa kegiatan penyuluhan dan pengumpulan data dilapangan selanjutnya data tersebut akan dijadikan referensi untuk pembangunan pembangkit listrik microhidro. Dalam penyuluhan ini metode yang akan digunakan adalah mengkombinasikan ceramah, diskusi, tutorial, praktik, dan tanya jawab. Metode kegiatan di tampilkan pada gambar 1 .

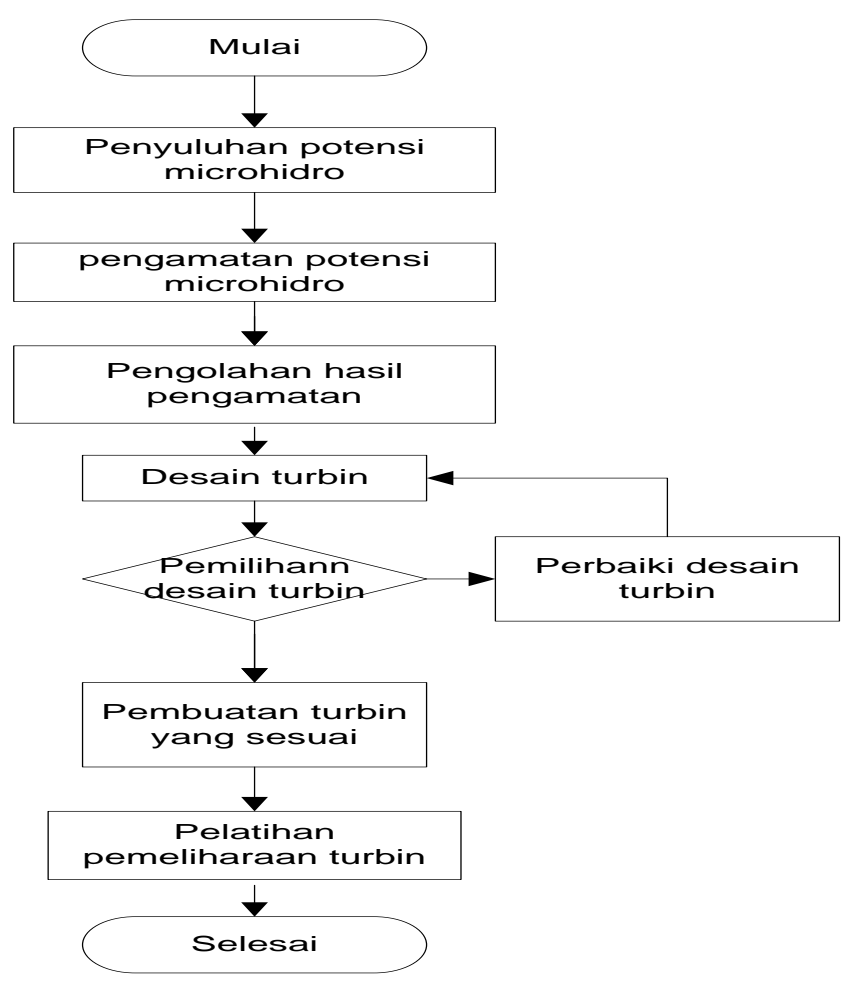

Gambar 1. Kerangka Tahapan Kegiatan 
Urutan metode kegiatan yaitu :

1. Mempelajari teori dan mengolah data yang ditemukan dari hasil tahap persiapan.

2. Menetukan jenis turbin yang akan digunakan untuk microhidro.

3. Melakukan fabrikasi turbin oleh masyarakat sekitar.

4. Langkah terakhir adalah pelatihan perawatan turbin oleh masyarakat

\section{PEMBAHASAN}

Secara umum lokasi PMLTH ini dipilih sesuai dengan kriteria sebagai berikut :

1. Mempunyai ketersediaan debit yang cukup.

2. Terdapat besarnya tinggi jatuh.
3. Kondisi topografi yang memungkinkan untuk penempatan fasilitas bangunan.

4. Berada tidak jauh dari daerah pelayanan.

5. Tidak mempengaruhi sistim pengairan yang sudah ada

Debit air dan tinggi jatuh air Data sumber tenaga air yang perlu diketahui adalah beda ketinggian permukaan (H) dan kapasitas aliran (Q). Kedua factor ini sangat menentukan besaran daya yang bisa dihasilkan oleh PLTMH. Umumnya suatu sumber tenaga air misalnya kapasitas alirannya berubah-ubah tergantung dari curah hujan serta faktor-faktor lainnya sangatlah berpengaruh. pada gambar 2 skema pembangkit listrik mikrohidro.

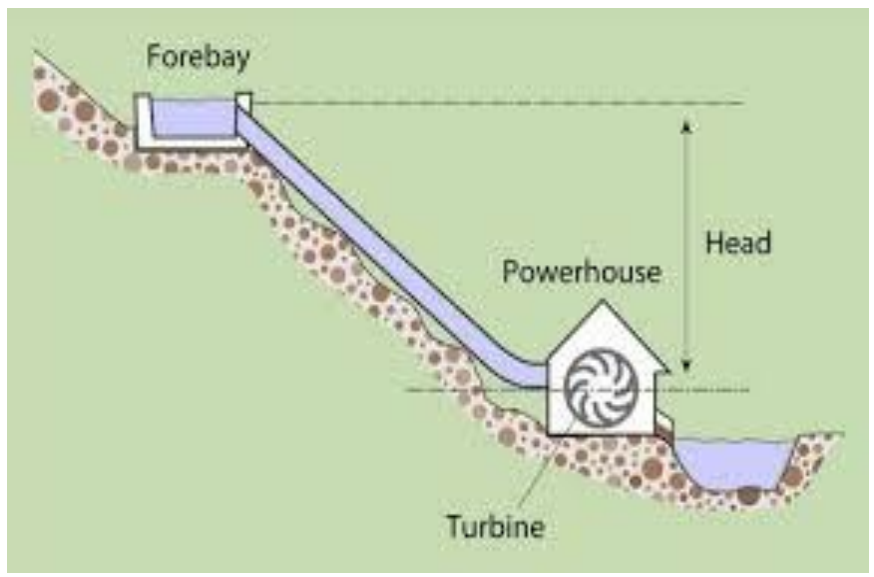

Gambar 2. Skema Pembangkit Listrik Mikrohidro

\subsection{Pengukuran profil lintasan dan analisa daya}

Pengukuran debit air dilakukan untuk mendapatkan nilai yang minimum dari debit air yang digunakan untuk pembangkit. Sebelum melakukan pengukuran debit air, hal yang dilakukan adalah mengukur panjang lintasan air yang akan digunakan sebagai penstock. Hasil pengukuran disajikan pada tabel 4. Data pengukuran panjang lintasan aliran sungai lebih dari 10 meter dengan rata-rata lebar sungai $150 \mathrm{~cm}$. pengukuran head dilakukan dengan menggunakan waterpas didapat selisih tinggi $5 \mathrm{~cm}$. Pengkuran debit air dilakukan dengan cara menggunakan ember sebagai wadah untuk menampung air dan stopwatch untuk mengetahui waktu berapa lama ember tersebut terisi. Spesifikasi ember yang digunakan mempunyai diameter $26 \mathrm{~cm}$ dengan ketinggian $37 \mathrm{~cm}$. sehingga ember tersebut mempunyai volume.

$$
\begin{aligned}
\mathrm{V} & =\pi r^{2} \cdot t \\
& =3 \cdot 14 \cdot 13^{2} \\
& =3 \cdot 14 \cdot 13^{2} \cdot 37 \\
& =19634,42 \mathrm{~cm}^{3}
\end{aligned}
$$

Tabel 1. Pengukuran debit mengunakan ember

\begin{tabular}{|l|l|}
\hline No & Waktu (detik) \\
\hline 1 & 2.2 \\
\hline 2 & 1.8 \\
\hline 3 & 1.3 \\
\hline 4 & 1.8 \\
\hline 5 & 2.4 \\
\hline 6 & 2.2 \\
\hline 7 & 2.4 \\
\hline$\sum$ & 14 \\
\hline
\end{tabular}

Dari tabel diatas rata-rata maka kecepatan rata- rata ember tersebut terisi adalah $t$ rata - rata $=\sum \frac{14}{7}=$ $2 d t$. Sehingga debit yang diperoleh

$$
Q=\frac{\text { Volume }}{t} \quad \mathrm{Q}=\frac{20}{2}=10 \mathrm{lt} / \mathrm{dt} \text {. Pengukuran }
$$
kecepatan aliran rata rata dengan jarak $3.10 \mathrm{~cm}$ disajikan pada tabel 2 . 
Tabel 2. Pengkuran kecepatan aliran

\begin{tabular}{|l|l|}
\hline No & $\begin{array}{l}\text { Waktu } \\
\text { (detik) }\end{array}$ \\
\hline 1 & 6.44 \\
\hline 2 & 5.87 \\
\hline 3 & 6.50 \\
\hline 4 & 7.00 \\
\hline 5 & 4.58 \\
\hline 6 & 5.16 \\
\hline 7 & 5.10 \\
\hline 8 & 4.91 \\
\hline 9 & 5.33 \\
\hline 10 & 4.81 \\
\hline$\sum$ & 55.72 \\
\hline
\end{tabular}

\section{Waktu rata-rata}

$$
\begin{aligned}
\text { trata } & =\frac{\text { total waktu }}{\text { pengukuran }} \\
t \text { rata } & =\frac{55.72}{10} \\
t \text { rata } & =5.572 d t
\end{aligned}
$$

Kecepatan aliran

$$
\begin{aligned}
v & =\frac{S}{t} \\
v & =\frac{3.10}{5.572} \\
v & =0.556 \mathrm{~m} / \mathrm{dt}
\end{aligned}
$$

\section{Analisa daya}

Dalam hal ini diketahui debit sungai $(\mathrm{Q})=10 \mathrm{l} / \mathrm{dt}, \mathrm{H}=$ $4.33 \mathrm{~m} . \mathrm{g}=9.8 \mathrm{~m} / \mathrm{sec}^{2}$

$$
\begin{gathered}
=9.8 \times 10 \times 4.33 \times 0.66 \\
=254.604 \mathrm{watt}
\end{gathered}
$$

\subsection{Pemilihan turbin air}

Pemilihan turbin kebanyakan didasarkan pada head air yang didapatkan dan kurang lebih pada rata-rata alirannya. Umumnya, turbin impuls digunakan untuk tempat dengan head tinggi, dan turbin reaksi digunakan untuk tempat dengan head rendah. Berdasarkan perhitungan dan pengukuran analisa daya yang didapat sebesar 254.604 watt maka turbin yang tepat adalah model kaplan, hal ini dilihat dari gambar 3. turbin untuk microhidro.

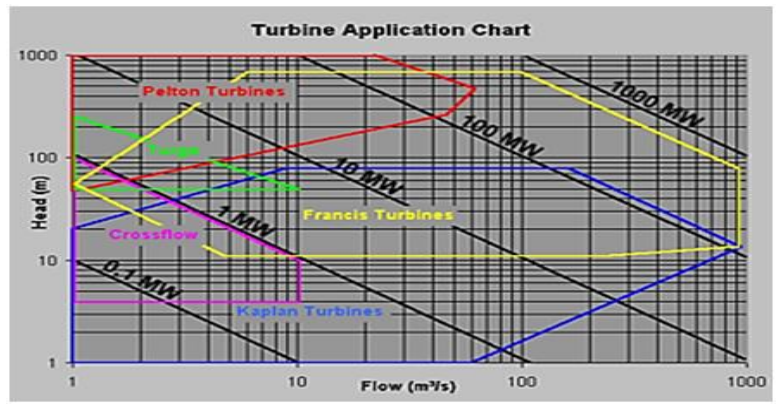

Gambar 3. Turbin untuk micro hidro
Konstruksi turbin vortek dalam kegiatan ini dibuat dengan memanfaatkan barang-barang yang mudah didapat dari lingkungan desa tersebut, bahan dan peralatan yang dibutuhkan antara lain :

1. Tangki air

2. Pulli

3. Generator

Berdasarkan data yang didapat dari kegiatan sebelumnya maka dirancanglah turbin dengan model Vortex, seperti disajikan pada gambar 4 dan 5Turbin vortex ini dirancang dengan 4 sudu masing masing sudu mempunyai sudut 90 derajat. Sudu ini terhubung dengan alternator sebagai pembangkit listrik dengan pulli yang mempunyai perbandingan $2: 1$. Turbin vortex ditempatkan pada sebuah drum air yang berfungsi untuk menimbulkan efek putaran air, sehingga secara alami turbin ini akan berputar karena terdorong oleh air yang mengalir melalui sebuah pipa penstock dengan diameter 4 inci sepanjang 6 meter. Gambar 4 Pengerjaan pembuatan turbin dilakukan di bengkel warga sehingga warga dapat membuat didampingi oleh tim.

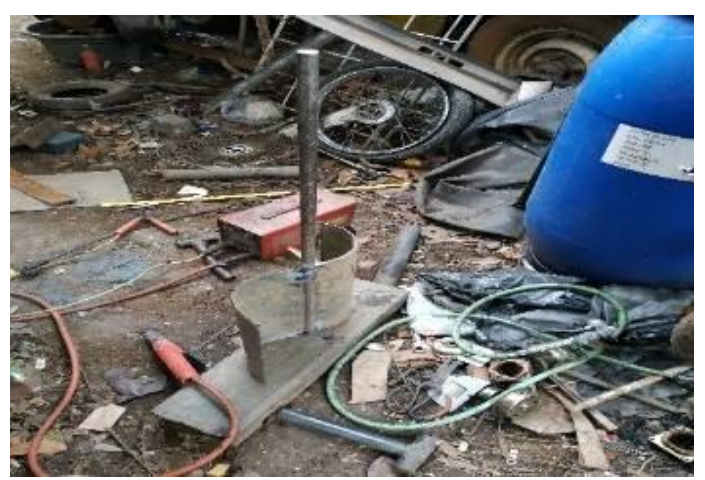

Gambar 4. Pembuatan kincir

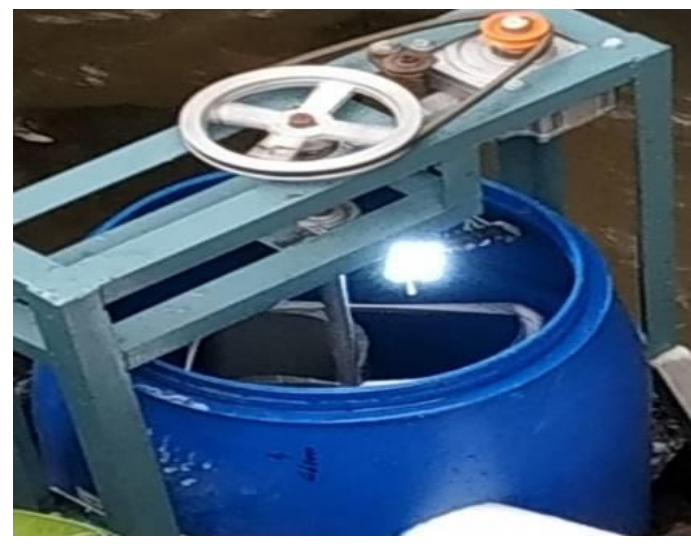

Gambar 5. Pemasangan

Pada Gambar 5 pembuatan turbin sudah lengkap dan dilakukan pemasangan turbin di saluran irigasi 


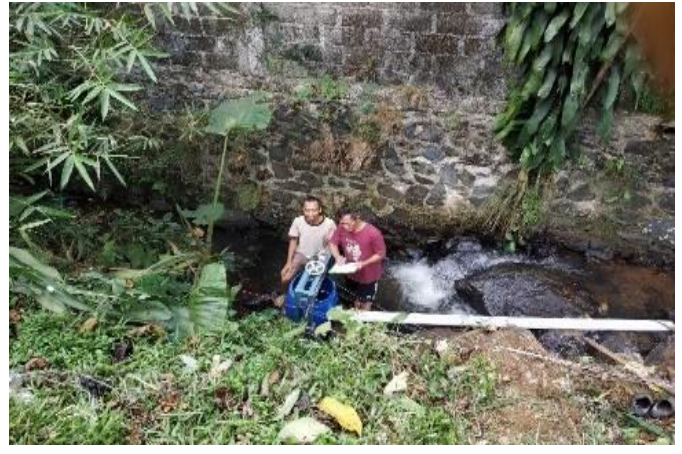

Gambar 6. Pengukuran

Terlihat pada Gambar 6 merupakan pengukuran tegangan pada generator sekaligus uji coba. Kegiatan pelatihan pemanfaatan saluran irigasi untuk pembangkit listrik microhidro kepada masyarakat di desa pamijahan gunung bunder dilakukan bersama warga sekitar.

Rasio antara pully turbin dengan generator adalah 1:2 Nilai tegangan listrik akan meningkat sesuai dengan putaran yang dihasilkan generator. Hasil listrik dari alternator disimpan pada sebuah baterai dengan tegangan $12 \mathrm{v}$. Hal ini dilakukan untuk menjaga kestabilan tegangan yang akan digunakan oleh peralatan listrik yang lain, tetapi peralatan listrik umumnya menggunakan tegangan AC 220v maka diperlukan sebuah inverter untuk merubah tegangan DC menjadi AC. Dengan sebuah baterai $12 \mathrm{~V}$ dan kuat arus 50 A. makan akan menghasilkan daya sebesar 600 watt. Daya tersebut memang cukup kecil karena belum seluruh dari potensi air digunakan untuk pembangkit listrik. Masih banyak air yang terbuang melalui sisi luar pipa penstock. Tabel 6 merupakan tegangan yang dihasilkan dari alternator.

Tabel 3. Tegangan yang dihasilkan dari putaran pulli

\begin{tabular}{|c|c|c|c|}
\hline No & $\begin{array}{c}\text { Putaran } \\
\text { pulli } 1 \\
\text { (RPM) }\end{array}$ & $\begin{array}{c}\text { Putaran pulli } \\
2(\text { RPM })\end{array}$ & Tegangan \\
\hline 1 & 87 & 174 & $12 \mathrm{v}$ \\
\hline 2 & 86 & 173 & $12 \mathrm{v}$ \\
\hline 3 & 76 & 151 & $11 \mathrm{v}$ \\
\hline 4 & 81 & 161 & $11 \mathrm{v}$ \\
\hline 5 & 88 & 176 & $13,5 \mathrm{v}$ \\
\hline 6 & 88 & 176 & $13,5 \mathrm{v}$ \\
\hline 7 & 86 & 172 & $11.5 \mathrm{v}$ \\
\hline 8 & 85 & 172 & $11,5 \mathrm{v}$ \\
\hline
\end{tabular}

Tegangan yang diharapkan untuk mengisi baterai adalah $13,5 \mathrm{v}$ tetapi dalam kenyataan nya tegangan yang dihasilkan rata rata adalah $12 \mathrm{~V}$ tentunya dengan tegangan sebesar $12 \mathrm{v}$ tidak maksimal untuk mengisi baterai. Hal ini kemungkinan disebabkan supplay air yang kurang stabil atau putaran alternator yang kurang kencang karena perbandingan rasio antar pulli yang kurang tepat. Dengan daya 600 watt pada baterai dan lampu LED 12v bisa menerangi 3 sampai 4 rumah dengan masing-masing rumah mendapat jatah lampu LED 12v 4 lampu.

\section{KESIMPULAN}

Saat ini masyarakat sudah mengetahui manfaat lain yaitu berguna sebagai pembangkit listrik microhidro. Masyarakat pun dapat membuat dan menerapkan turbin untuk microhidro secara sederhana, kemudian masyarakat juga berperan aktif dalam pemeliharaan perangkat turbin maupun kebersihan disepanjang aliran sungai dan melakukan penghijuan. Dari pengujian hanya didapat daya sebesar 600 watt tetapi potensi sungai tersebut belum sepenuhnya digunakan hal ini disebabkan belum optimalnya desain dari aliran penstok. Sehingga semburan air untuk menggerakan sudu-sudu turbin tidak maksimal

\section{SARAN}

Kegiatan pengabdian pada masyarakat ini dapat dilanjutkan dengan lebih banyak melibatkan masyarakat terutama dalam perawatan terhadap sistem dan lingkungan. Sistem pembangkit listrik microhidro dengan turbin vortex ini sebenarnya sesuai dengan karakter dari sungai tersebut tetapi masih perlu disempurnakan terutama pada bagian pipa penstock dan sudu-sudu turbin.

\section{DAFTAR PUSTAKA}

Bahtiar, A., Hidayat, D., M. and J.M., Syakir, N and Wibawa, B. . 2015. Aplikasi Pembangkit Listrik Mikrohidro Untuk Penerangan Lingkungan Masyarakat Di Kecamatan Ciwidey Kabupaten Bandung, Jurnal Aplikasi Ipteks untuk Masyarakat, 4(1), pp. 15-17.

Budiarso Muhammad Ridho dan Raza Dianofitra, A. P. H. 2014. Optimasi Turbin Mikrohydro untuk Daerah Terpencil: Openflume, Proceeding Seminar Nasional Tahunan Teknik Mesin XIII (SNTTM XIII), (Snttm Xiii), pp. 15-16.

Farid rahman, priyo heru. 2018. Uji Eksperimental Kinerja Turbin Reaksi Aliran Vortex Tipe Sudu Berpenampang Lurus Dengan Variasi Tinggi Sudu Muhammad Farid Rahman Hakim, JTM, 06(01), pp. 85-95.

Febijanto, I. 2011. Pemanfaatan Potensi Tenaga Air Di Saluran Irigasi Banjarcahyana, Kabupaten Banjarnegara, Propinsi Jawa Tengah Sebagai Usaha Pengurangan Emisi Gas Rumah Kaca, Jurnal Teknologi Lingkungan, 9(3), pp. 277-286. doi: 10.29122/jtl.v9i3.472.

Nasir, B. A. 2013. Design of Micro -Hydro -Electric Power Station, International Journal of Engineering and Advanced Technology, 2(5), pp. 39-47. Available at: http://citeseerx.ist.psu.edu/viewdoc/download?doi $=10.1 \cdot 1.674 .5491 \&$ rep=rep1\&type=pdf.

Prabowo, Y. et al. 2018. Studi Kelayakan Pembangkit Listrik Tenaga Mikrohidro (Pmlth) Pada Saluran 
Irigasi Gunung Bunder Pamijahan Bogor, Jurnal Ilmiah FIFO, 10(1), p. 41. doi: 10.22441/fifo.v10i1.2939.

Pranoto, B. et al. 2018. Potensi Energi Mikrohidro di Daerah Irigasi (Studi Kasus di Wilayah Sungai Serayu Opak), Jurnal Irigasi, 12(2), p. 77. doi: 10.31028/ji.v12.i2.77-86.

Safii, M. and Vidy. 2019. Perancangan Bangun Alat Monitoring Notifikasi Tegangan Genset Berbasis Internet of Things Dan Sms Gateway, p. 7. Available at: http://jurnal.wicida.ac.id/index.php/sebatik/article /view/466/172.

Shantika, D. 2013. Perancangan Prototipe Piko Hydro PORTABLE 200 Watt, Seminar Nasional XII Rekayasa dan Aplikasi Teknik Mesin di Industri, Kampus ITENAS - Bandung, 17-18 Desember 2013.
Sihombing, R. P. J. et al. 2014. Analisa Efisiensi Turbin Vortex Dengan Casing Berpenampang Lingkaran Pada Sudu Berdiameter 56 Cm Untuk 3 Variasi Jarak Sudu Dengan Saluran Keluar', $e$-, 10(2), pp. 143-148.

Subandono, A. 2013. Pembangkit listrik tenaga mikrohidro ( pltmh ), ADITYA - Pendidikan Bahasa dan Sastra Jawa, 10(4), pp. 1-13. doi: 10.17529/jre.v10i4.1113.

Syafitri, N. F. et al. 2018. Analisis Profil Sudu Turbin Mikro Hidro Vortex , Seminar Nasional Cendekiawan, pp. 535-541.

Zainuddin, H. et al. (2009) 'Design and Development of Pico-hydro Generation System for Energy Storage Using Consuming Water Distributed to Houses', Water, 3(11), pp. 154-159. 